\title{
Electrocoagulation of Disperse Dyebath Wastewater: Optimization of Process Variables and Sludge Production
}

\author{
Ahmet Aygun ${ }^{1 *}$, Bilgehan $\mathrm{Nas}^{2}$, and Mehmet Faik Sevimli ${ }^{3}$ \\ ${ }^{1}$ Bursa Technical University, Faculty of Engineering and Natural Sciences, Department of Environmental Engineering, \\ 16310 Bursa, Turkey \\ ${ }^{2}$ Konya Technical University, Faculty of Engineering and Natural Sciences, Department of Environmental Engineering, \\ 42003 Konya, Turkey \\ ${ }^{3}$ KTO Karatay University, Engineering Faculty, Department of Civil Engineering, 42003 Konya, Turkey
}

\begin{abstract}
This study was conducted to investigate the effect of initial $\mathrm{pH}$, current density, and electrolysis time on process performance in terms of decolorization and chemical oxygen demand (COD) removal from disperse dyebath wastewater (DDW) by mono-polar parallel laboratory scale electrocoagulation (EC) process. COD reduction of $51.3 \%$ and decolorization of $92.8 \%$ were obtained with operating cost of $0.19 € / \mathrm{m}^{3}$ treated wastewater for Al-Al electrode pair, while $90.5 \%$ of decolorization and $49.2 \%$ of COD reduction were obtained with operating cost of $0.20 € / \mathrm{m}^{3}$ treated wastewater for an Fe-Fe electrode pair. The amount of sludge production were highly related to type of the electrode materials. At the optimum conditions, the amount of sludge produced were $0.18 \mathrm{~kg} / \mathrm{m}^{3}$ and $0.28 \mathrm{~kg} / \mathrm{m}^{3}$ for Al-Al and Fe-Fe electrode pairs, respectively. High decolorization can be explained by the hydrophobic nature of the disperse dye, while limited COD removal was observed due to the high dissolved organic matter of the DDW based on auxiliary chemicals. Energy, electrode, and chemical consumptions and sludge handling were considered as major cost items to find a cost-effective and sustainable solution for EC. The contribution of each cost items on operating cost were determined as $10.0 \%, 51.1 \%, 30.5 \%$ and $8.4 \%$ for $\mathrm{Al}-\mathrm{Al}$, and they were also determined as $9.0 \%, 38.0 \%, 40.5 \%$ and $12.5 \%$ for $\mathrm{Fe}-\mathrm{Fe}$, respectively. COD reduction and decolorization were fitted to first-order kinetic rule.
\end{abstract}

Keywords : Auxiliary Chemicals, Decolorization, Disperse Dye, Electrocoagulation, Optimization

Received : 13 February 2020, Accepted : 27 August 2020

\section{Introduction}

The textile sector generates colored wastewater that is heavily polluted with generally synthetic dyes, auxiliaries, and salts [1]. Thus, textile wastewater discharged into a freshwater environment has become crucial issue. Especially colored discharges have shown to cause toxic effects on aquatic flora and reduced light transmittance directly prevents photosynthetic activity [2].

Synthetic dyes are classified into azoic, reactive, disperse, direct, acid, basic, sulfur, mordant, and vat

*E-mail address: ahmet.aygun@btu.edu.tr

DOI: https://doi.org/10.33961/jecst.2020.00787

This is an open-access article distributed under the terms of the Creative Commons Attribution Non-Commercial License (http://creativecommons.org/licenses/by-nc/4.0) which permits unrestricted non-commercial use, distribution, and reproduction in any medium, provided the original work is properly cited. dyes based upon their chemical composition and the method of their application in the dyeing process [3]. The most common allergen dyes which adversely affects the immune system by penetrating through the skin are disperse ones characterized by lipophilic behavior and low molecular weights [4]. Concern arises, as many disperse dyes are made from known carcinogens such as azo and nitro-compounds [5]. Anthraquinone-based disperse dyestuffs are the most resistant ones to biological and chemical reduction due to their aromatic ring structure [6].

Disperse dyestuffs characterized by non-ionic small particles which have aqueous dispersions insoluble at room temperature and substantivity to hydrophobic fibers [7]. Thus, these dyes are suitable for dyeing of polyester, cellulose acetate, nylon and acrylic fibers [8]. Dyeing of polyester fibers is very difficult in normal conditions due to the high crystal- 
line structure of the fibers, the hydrophobic character and the absence of effective functional groups in which the dye molecules can form chemical bonds. Therefore, the dyeing process can be carried out at high temperatures (up to $130^{\circ} \mathrm{C}$ ) for the fibers to be dyed efficiently [9]. Dye particles are stabilized with dispersing agents used as auxiliary chemicals. In order to avoid problems during the dyeing process with disperse dyestuffs, the $\mathrm{pH}$ of the flotte should be kept between 4.5 and 5.5 [10]. It is recommended to adjust the $\mathrm{pH}$ of the dyebath with organic acid (i.e. acetic acid) for better adsorption onto the fiber [11]. The quantity of dye lost in the discharged effluent is estimated to be around $10 \%$ for disperse dyes [12].

Biological methods, especially activated sludge, are preferred to treat textile wastewater; because they are generally cheap and capable to remove organic pollutants and dyes [13]. Disperse dyebath wastewater (DDW) cannot be readily bio-degraded, because the structures of most commercial dye compounds are generally complex and most of them are non-biodegradable [14]. The dyestuff and organic pollutants in textile wastewater can be effectively removed by conventional methods such as chemical coagulation [15], advanced oxidation [16] and adsorption [17], electrooxidation [18]; but, the operating cost of these treatment methods are relatively high. To treat nonbiodegradable material in textile wastewater by conventional methods is required more chemicals and energy consumptions comparing to electrocoagulation (EC) proces. Therefore, EC process started to commonly used to treat wastewater containing textile dyes [19-24]. EC used to overcome some problems caused by other treatment methods. Additionally, EC have some advantages such as less sludge production, small area requirement and low initial investment cost [25-27].

Most of studies have been focused on treatment of synthetically prepared dye solution using lab-scale EC process in a batch mode. Based on previous studies, decolorization varies between $85-100 \%$ while COD reduction changed from $40 \%$ up to $80 \%$ at optimized operating conditions $[28,29]$. Initial $\mathrm{pH}$, current density, current efficiency, electrode material (aluminum, iron or stainless steel), electrode connection type (monopolar parallel or serial, and bipolarserial), electrolysis time, inner-electrode distance and temperature have been determined as important factors for process efficiency [30-32]. Electrochemical, chemical and physical processes, which occur simultaneously or sequentially in the EC, complicate the description of the pollutant removal mechanism $[33,34]$. It is reported that EC is very efficient in treatment of wastewater containing dye with low energy consumption $[25,35]$.

The management of sludges generated in treatment plants is of importance that they cannot be neglected when the treatment costs of treatment sludges are taken into consideration. The amount of monomeric and polymeric precipitates based on Al$\mathrm{Al}$ and $\mathrm{Fe}-\mathrm{Fe}$ electrode pairs differ due to the auxiliary chemicals used in the textile sector. Therefore, it is of great importance to determine the sludge amount generated from the EC process.

Traditionally, optimization has been carried out by monitoring the influence of one factor at a time on response to find the best solution [36]. Its major drawback is that it does not represent the interactive effects among the independent variables on response. At the same time, the one-factor optimization increases the number of experimental runs, which is often very expensive or highly time-consuming approach [37,38]. Response Surface Methodology (RSM) is a combination of mathematical and statistical methods to design the experiments, useful to improve and optimize the process performance [39]. RSM can be used to developed satisfactory relation between response and EC variables with a limited number of experiments [40] Analysis of variance (ANOVA) is a statistical method used to determine the significant effects of variables and goodness of fitted models [41].

Dye removal from the textile wastewaters by EC is widely studied; however, limited studies are available about the effect of dyeing auxiliaries (acetic acid and dispersing agent) on the process performance with the lowest cost. Therefore, the main aims of the study are (i) to determine optimum operating conditions with cost-effective approach using both Al-Al and $\mathrm{Fe}-\mathrm{Fe}$ sacrificial electrode pairs to remove COD and decolarization for DDW consisting of the disperse dyes and dyeing auxiliaries, (ii) to predict the COD reduction and decolorization rates satisfactorily by kinetic assessment, and (iii) to reveal the relationship between electrode consumption and sludge production. 


\section{Materials and Methods}

\subsection{Synthetic and real industrial disperse dyebath wastewater (DDW)}

Synthetic DDW was prepared on the basis of typical disperse dyeing recipe obtained from a local textile manufacturer using $120 \mathrm{mg} / \mathrm{L}$ disperse dyes (by mixing three dyes: $5 \mathrm{mg} / \mathrm{L}$ of Disperse Yellow 241 (STPRS YEL CE5G), $100 \mathrm{mg} / \mathrm{L}$ of Disperse Red 362 (STPRS PNK FBSM), and $15 \mathrm{mg} / \mathrm{L}$ of Disperse Blue (STPRS RBN CERN), $1.5 \mathrm{~g} / \mathrm{L}$ dispersing agent and $1.5 \mathrm{~g} / \mathrm{L}$ acetic acid. In addition, $1 \mathrm{~g} / \mathrm{L} \mathrm{NaCl}$ was added to reduce the energy cost by increasing conductivity and reducing the potential difference [19]. $10 \%$ of the disperse dyes and all of the dye auxiliaries were assumed to remain in the DDW. In order to verify the results obtained with synthetic wastewater, real wastewater was collected from the local textile manufacturer's disperse dyebath effluent. Characterizations of synthetic and real disperse dyebath wastewater are presented in Table 1.

\subsection{Experimental procedure}

The experimental setup used in this study has been described in our previous publication [42]. At the beginning of each run, $\mathrm{NaOH}$ was used to set the $\mathrm{pH}$, and $200 \mathrm{rpm}$ mixing rate in the EC reactor was kept constant throughout the batch experiment at room temperature. Then, the supernatant was collected from the EC and filtered using glass fiber filters ( $0.45 \mathrm{~mm}$ microspore) to find decolorization and COD reduction rate. Electrode consumption and the amount of genereted sludge were determined using the methods suggested by previous studies $[28,43]$.

\subsection{Response Surface Method}

Design Expert software package, version 11.0.3 (Stat-Ease Inc., MN, USA) was used for the schedul- ing the experiments and data analysis. Design of Experiments (DoE) is a powerful technique to optimize process performance and it has been broadly implemented in process design and development. A three-factor and a five-level central composite design (CCD) consisting of 17 runs were conducted including three replicates at the center point $(a=0)$ for Al$\mathrm{Al}$ and Fe-Fe electrode pair. The coded process variables at five levels between -1.68 and +1.68 at the actual ranges determined according to preliminary experimental studies and literature surveys and presented in Table 2.

In our study, the polynomial function including quadratic terms allows to predict the responses (COD removal $\left(\mathrm{Y}_{\mathrm{COD}}, \%\right)$, decolorization $\left(\mathrm{Y}_{525} \%\right)$ for $\mathrm{Al}$ $\mathrm{Al}$ and $\mathrm{Fe}-\mathrm{Fe}$ electrode pairs) based on the independent variables $\left(\mathrm{X}_{1}, \mathrm{X}_{2}\right.$ and $\left.\mathrm{X}_{3}\right)$ at selected range. The experimental findings were evaluated by the analysis of variance (ANOVA) in the confidence level of $95 \%$. Backward elimination procedure was used to exclude the non-significant terms ( $p$ value $>0.05$ ).

\subsection{Analytical Methods}

All chemicals were of analytical grade obtained from Merck. Disperse dye auxiliary and dyestuffs were obtained from local manufacturer. Three wavelengths, $436 \mathrm{~nm}, 525 \mathrm{~nm}$, and $620 \mathrm{~nm}$, were chosen to determine the apparent color based on EN ISO 7887. Decolorization was only presented in terms of absorbance at $525 \mathrm{~nm}$, because of the dominant wavelength was $525 \mathrm{~nm}$ for DDW. Closed reflux col-

Table 2. Independent process variables and their ranges

\begin{tabular}{ccc}
\hline \hline Variables & Unit & Range \\
\hline Initial $\mathrm{pH}\left(\mathrm{X}_{1}\right)$ & - & $4.0-9.0$ \\
Current density $\left(\mathrm{X}_{2}\right)$ & $\mathrm{A} / \mathrm{m}^{2}$ & $9.8-60.2$ \\
Electrolysis time $\left(\mathrm{X}_{3}\right)$ & $\mathrm{min}$ & $1.6-18.4$ \\
\hline
\end{tabular}

Table 1. Characterization of synthetic and real disperse dyebath wastewater

\begin{tabular}{|c|c|c|c|c|c|c|}
\hline \multirow{2}{*}{ Parameter } & & \multirow{2}{*}{ Unit } & \multicolumn{2}{|c|}{ Synthetic } & \multicolumn{2}{|c|}{ Real } \\
\hline & & & Value & $\mathrm{SD}( \pm)$ & Value & $\mathrm{SD}( \pm)$ \\
\hline \multirow{3}{*}{ Color } & $436 \mathrm{~nm}$ & $\mathrm{~cm}^{-1}$ & 0.459 & 0.03 & 0.543 & 0.04 \\
\hline & $525 \mathrm{~nm}$ & $\mathrm{~cm}^{-1}$ & 0.958 & 0.05 & 0.830 & 0.06 \\
\hline & $620 \mathrm{~nm}$ & $\mathrm{~cm}^{-1}$ & 0.327 & 0.03 & 0.417 & 0.03 \\
\hline COD & & $\mathrm{mg} / \mathrm{L}$ & 3530 & 93 & 3200 & 85 \\
\hline $\mathrm{pH}$ & & - & 3.37 & 0.1 & 3.45 & 0.1 \\
\hline
\end{tabular}


orimetric method (SM 5220 C) was used for COD analysis. WTW $340 \mathrm{i}$ model $\mathrm{pH}$ meter was used to measure $\mathrm{pH}$.

\subsection{Operating Cost}

Electricity, electrode material, and chemical consumption are considered to determine the operating cost by using followed equation (Eq. 1) for treatment of DDW:

$$
\begin{aligned}
\text { Operating Cost }= & \alpha \cdot C_{\text {Chemical }}+\beta \cdot C_{\text {Electricity }} \\
& +\gamma \cdot C_{\text {Electrode }}+\eta \cdot C_{\text {Sludge }}
\end{aligned}
$$

where $\mathrm{C}_{\text {Chemical }}$ is the chemical consumption $\left(\mathrm{kg} / \mathrm{m}^{3}\right)$, $\mathrm{C}_{\text {Electricity }}$ is the electricity consumption $\left(\mathrm{kWh} / \mathrm{m}^{3}\right)$, $\mathrm{C}_{\text {Electrode }}$ is the electrode consumption $\left(\mathrm{kg} / \mathrm{m}^{3}\right)$, and $\mathrm{C}_{\text {sludge }}$ is the amount of generated sludge $\left(\mathrm{kg} / \mathrm{m}^{3}\right)$ were determined based on previous studies [44]. The unit prices for electrical energy, electrode materials
(Al and $\mathrm{Fe}$ ) and sodium hydroxide from Turkish market used in calculating the operating cost were $0.072 € / \mathrm{kWh}, 1.65 € / \mathrm{Kg}$ for $\mathrm{Al}$ electrode, $0.85 € / \mathrm{Kg}$ for Fe electrode and $0.40 € / \mathrm{Kg}$, respectively. The cost of sludge handling was $0.09 € / \mathrm{Kg}$.

\section{Results and Discussion}

\subsection{Prediction of model equations and statistical analysis}

Initial $\mathrm{pH}$, current density and electrolysis time which were determined as the most important operating parameters were optimized by using approximating functions based on the data given in literature (XXX). CCD were selected to reduce the number of experiments and to reveal the combined effect of the independent variables on process performance in terms of COD reduction and decolorization for both $\mathrm{Al}-\mathrm{Al}$ and $\mathrm{Fe}-\mathrm{Fe}$ electrode pair (Table 3).

\begin{tabular}{|c|c|c|c|c|c|c|c|c|c|c|c|c|c|c|c|c|c|}
\hline \multirow{3}{*}{ Run } & \multirow{2}{*}{\multicolumn{3}{|c|}{ Variables }} & \multicolumn{14}{|c|}{ Responses } \\
\hline & & & & \multicolumn{7}{|c|}{ Al-Al electrode pair } & \multicolumn{7}{|c|}{ Fe-Fe electrode pair } \\
\hline & $\mathrm{X}_{1}$ & $\mathrm{X}_{2}$ & $\mathrm{X}_{3}$ & $\begin{array}{l}\text { CR } \\
\lambda_{525} \\
(\%)\end{array}$ & $\begin{array}{c}\text { COD } \\
(\%)\end{array}$ & $\begin{array}{l}\mathrm{C}_{\text {Energy }} \\
\left(€ / \mathrm{m}^{3}\right)\end{array}$ & $\begin{array}{c}\mathrm{C}_{\text {Electrode }} \\
\left(€ / \mathrm{m}^{3}\right)\end{array}$ & $\begin{array}{c}\mathrm{C}_{\text {Chemical }} \\
\left(€ / \mathrm{m}^{3}\right)\end{array}$ & $\begin{array}{l}\mathrm{C}_{\text {Sludge }} \\
\left(€ / \mathrm{m}^{3}\right)\end{array}$ & $\begin{array}{c}\text { Total } \\
\text { Cost } \\
\left(€ / \mathrm{m}^{3}\right)\end{array}$ & $\begin{array}{l}\text { CR } \\
\lambda_{525} \\
(\%)\end{array}$ & $\begin{array}{c}\text { COD } \\
(\%)\end{array}$ & $\begin{array}{l}\mathrm{C}_{\text {Energy }} \\
\left(€ / \mathrm{m}^{3}\right)\end{array}$ & $\begin{array}{l}C_{\text {Electrode }} \\
\left(€ / \mathrm{m}^{3}\right)\end{array}$ & $\begin{array}{c}C_{\text {Chemical }} \\
\left(€ / \mathrm{m}^{3}\right)\end{array}$ & $\begin{array}{l}\mathrm{C}_{\text {Sludge }} \\
\left(€ / \mathrm{m}^{3}\right)\end{array}$ & $\begin{array}{c}\text { Total } \\
\text { Cost } \\
\left(€ / \mathrm{m}^{3}\right)\end{array}$ \\
\hline 1 & 6.5 & 35.0 & 10.0 & 92.38 & 43.2 & 0.04 & 0.08 & 0.09 & 0.03 & 0.23 & 89.25 & 44.2 & 0.04 & 0.09 & 0.09 & 0.05 & 0.26 \\
\hline 2 & 6.5 & 60.2 & 10.0 & 96.24 & 42.5 & 0.13 & 0.13 & 0.09 & 0.05 & 0.39 & 92.38 & 42.7 & 0.11 & 0.15 & 0.09 & 0.07 & 0.43 \\
\hline 3 & 6.5 & 35.0 & 1.6 & 80.38 & 15.7 & 0.01 & 0.02 & 0.09 & 0.02 & 0.13 & 55.44 & 10.7 & 0.01 & 0.02 & 0.09 & 0.01 & 0.13 \\
\hline 4 & 5.0 & 20.0 & 5.0 & 87.37 & 25.8 & 0.01 & 0.02 & 0.07 & 0.02 & 0.12 & 64.10 & 22.6 & 0.01 & 0.03 & 0.07 & 0.02 & 0.12 \\
\hline 5 & 3.9 & 35.0 & 10.0 & 88.20 & 41.3 & 0.04 & 0.09 & 0.03 & 0.03 & 0.18 & 71.82 & 38.2 & 0.04 & 0.09 & 0.03 & 0.04 & 0.20 \\
\hline 6 & 6.0 & 35.0 & 10.0 & 94.26 & 45.5 & 0.04 & 0.08 & 0.09 & 0.02 & 0.23 & 89.35 & 42.3 & 0.04 & 0.09 & 0.09 & 0.04 & 0.26 \\
\hline 7 & 8.0 & 50.0 & 15.0 & 86.12 & 48.4 & 0.15 & 0.17 & 0.12 & 0.05 & 0.48 & 91.34 & 46.4 & 0.14 & 0.20 & 0.12 & 0.10 & 0.55 \\
\hline 8 & 5.0 & 50.0 & 15.0 & 99.79 & 55.2 & 0.15 & 0.15 & 0.07 & 0.05 & 0.42 & 98.23 & 52.2 & 0.14 & 0.20 & 0.07 & 0.10 & 0.50 \\
\hline 9 & 8.0 & 20.0 & 5.0 & 79.65 & 21.2 & 0.01 & 0.03 & 0.12 & 0.02 & 0.17 & 74.74 & 20.9 & 0.01 & 0.03 & 0.12 & 0.02 & 0.17 \\
\hline 10 & 5.0 & 50.0 & 5.0 & 90.08 & 28.1 & 0.05 & 0.05 & 0.07 & 0.02 & 0.19 & 71.19 & 25.7 & 0.05 & 0.07 & 0.07 & 0.03 & 0.21 \\
\hline 11 & 5.0 & 20.0 & 15.0 & 89.25 & 51.5 & 0.02 & 0.08 & 0.07 & 0.03 & 0.20 & 91.44 & 50.4 & 0.02 & 0.08 & 0.07 & 0.03 & 0.20 \\
\hline 12 & 6.5 & 35.0 & 18.4 & 98.85 & 54.6 & 0.07 & 0.14 & 0.09 & 0.05 & 0.35 & 94.57 & 53.2 & 0.06 & 0.17 & 0.09 & 0.08 & 0.40 \\
\hline 13 & 6.5 & 35.0 & 10.0 & 94.05 & 45.5 & 0.04 & 0.08 & 0.09 & 0.02 & 0.23 & 91.34 & 42.2 & 0.04 & 0.09 & 0.09 & 0.04 & 0.25 \\
\hline 14 & 8.0 & 50.0 & 5.0 & 85.18 & 26.5 & 0.05 & 0.06 & 0.11 & 0.02 & 0.24 & 67.22 & 23.5 & 0.05 & 0.07 & 0.11 & 0.03 & 0.26 \\
\hline 15 & 9.0 & 35.0 & 10.0 & 72.34 & 39.8 & 0.04 & 0.08 & 0.12 & 0.02 & 0.26 & 83.30 & 37.6 & 0.04 & 0.09 & 0.12 & 0.04 & 0.29 \\
\hline 16 & 6.5 & 9.8 & 10.0 & 85.70 & 37.8 & 0.01 & 0.03 & 0.09 & 0.02 & 0.14 & 85.39 & 35.1 & 0.01 & 0.03 & 0.09 & 0.02 & 0.14 \\
\hline 17 & 8.0 & 20.0 & 15.0 & 80.17 & 51.9 & 0.02 & 0.07 & 0.11 & 0.02 & 0.22 & 90.18 & 48.4 & 0.02 & 0.08 & 0.11 & 0.05 & 0.25 \\
\hline
\end{tabular}

Table 3. Experimental planning and actual responses obtained in the experiments

$\mathrm{CR}_{525}$ : Color removal at $525 \mathrm{~nm}$ 
The experimental results were analyzed by RSM. An empirical relationship expressed by a secondorder polynomial equation between process variables and responses according the results. The fitted second-order models in terms of coded factors can be used to explain COD reduction and decolorization. The fitted models are given in Eq. 2 and for Al-Al electrode pair and Eq. 4 and 5 for $\mathrm{Fe}-\mathrm{Fe}$ electrode pair:

$$
\begin{aligned}
\mathrm{Al} \text { electrode; } & \\
Y_{C R_{525 n n}=} & +91.52-4.54 \mathrm{x}_{1}+3.11 \mathrm{x}_{2} \\
& +3.23 \mathrm{x}_{3}-4.09 \mathrm{x}_{1}{ }^{2} \\
Y_{C O D}= & +44.71-1.11 \mathrm{x}_{1}+1.15 \mathrm{x}_{2} \\
& +12.51 \mathrm{x}_{3}-1.41 \mathrm{x}_{1}{ }^{2}-1.55 \mathrm{x}_{2}{ }^{2}-3.32 \mathrm{x}_{3}{ }^{2}
\end{aligned}
$$

Fe electrode;

$$
\begin{aligned}
Y_{C R_{525 n n}=} & +89.74+1.31 \mathrm{x}_{1}+1.41 \mathrm{x}_{2}+11.70 \mathrm{x}_{3} \\
& -2.53 \mathrm{x}_{1} \mathrm{x}_{2}-4.10 \mathrm{x}_{1}{ }^{2}-5.00 \mathrm{x}_{3}{ }^{2} \\
Y_{C O D}= & +42.87-0.9306 \mathrm{x}_{1}+1.34 \mathrm{x}_{2}+12.90 \mathrm{x}_{3} \\
& -1.68 \mathrm{x}_{1}{ }^{2}-1.32 \mathrm{x}_{2}{ }^{2}-3.78 \mathrm{x}_{3}{ }^{2}
\end{aligned}
$$

The signs in front of the fitted model terms can be used to explain the type of effect (synergistic or antagonistic) on response. It was observed that, when the value of positive sign terms in models was increased, it leads to an increase in COD reduction and decolorization. The terms with negative signs have diminishing effect on response. The generated models for both of Al-Al and Fe-Fe electrode pair fitted very well to the actual results for treatment of DDW by EC. The model must be generated appropriately to avoid poor or ambiguous results [45]. After discarding the non-significant terms by backward elimination process at $p<0.05$, the fitted models were regenerated only with statistically significant terms and were tested by ANOVA (Table 4).

Based on previous study, for a good fitting of experimental results with proposed models, $\mathrm{R}^{2}$ and AP should be at least 0.80 and 4, respectively [28]. Adjusted $\mathrm{R}^{2}$ indicates how well terms fit a curve or line but adjusts for the number of terms in a model. If the model contains a large number of non-significant terms, the $\mathrm{R}_{\text {adjusted value will be decrease. The value }}^{2}$ of $R_{\text {adjusted }}^{2}$ is equal to or less than $R^{2}$. In addition, the closeness of $R^{2}$ adjusted and Pred- $R^{2}$ values (allowable value 0.2 ) is indicative of a statistically successful model [46]. Most of the CV values were less than 5\% which represents great precision and reliability for

\begin{tabular}{|c|c|c|c|c|c|c|c|c|c|c|}
\hline Response & Elc. & $\mathrm{R}^{2}$ & $\mathrm{R}_{\text {adj }}^{2}$ & Pred-R ${ }^{2}$ & SD & $\mathrm{CV}$ & PRESS & F-value & Prob $>F$ & $\mathrm{AP}$ \\
\hline $\mathrm{CR} \lambda_{525}(\%)$ & \multirow{6}{*}{$\mathrm{Al}$} & 0.88 & 0.85 & 0.78 & 2.91 & 3.29 & 195.14 & 22.92 & $<0.0001$ & 16.50 \\
\hline COD $(\%)$ & & 0.98 & 0.97 & 0.95 & 1.98 & 5.00 & 116.03 & 97.47 & $<0.0001$ & 33.06 \\
\hline $\mathrm{C}_{\text {Energy }}\left(€ / \mathrm{m}^{3}\right)$ & & 0.98 & 0.97 & 0.94 & 0.008 & 15.74 & 0.0019 & 148.22 & $<0.0001$ & 33.53 \\
\hline $\mathrm{C}_{\text {Electrode }}\left(€ / \mathrm{m}^{3}\right)$ & & 0.99 & 0.99 & 0.98 & 0.005 & 6.13 & 0.0008 & 282.83 & $<0.0001$ & 52.66 \\
\hline $\mathrm{C}_{\text {Chemical }}\left(€ / \mathrm{m}^{3}\right)$ & & 0.94 & 0.93 & 0.89 & 0.0062 & 7.08 & 0.0010 & 226.78 & $<0.0001$ & 39.96 \\
\hline Total Cost $\left(€ / \mathrm{m}^{3}\right)$ & & 0.98 & 0.97 & 0.92 & 0.018 & 8.09 & 0.0109 & 74.82 & $<0.0001$ & 27.93 \\
\hline $\mathrm{CR}_{525}(\%)$ & \multirow{6}{*}{$\mathrm{Fe}$} & 0.96 & 0.94 & 0.85 & 3.17 & 3.85 & 367.24 & 39.62 & $<0.0001$ & 19.32 \\
\hline COD $(\%)$ & & 0.99 & 0.98 & 0.96 & 1.65 & 4.42 & 94.67 & 150.78 & $<0.0001$ & 40.89 \\
\hline $\mathrm{C}_{\text {Energy }}\left(€ / \mathrm{m}^{3}\right)$ & & 0.94 & 0.93 & 0.90 & 0.012 & 26.05 & 0.0032 & 67.63 & $<0.0001$ & 24.52 \\
\hline $\mathrm{C}_{\text {Electrode }}\left(€ / \mathrm{m}^{3}\right)$ & & 0.99 & 0.99 & 0.99 & 0.0021 & 2.25 & 0.0001 & 4000 & $<0.0001$ & 178.3 \\
\hline $\mathrm{C}_{\text {Chemical }}\left(€ / \mathrm{m}^{3}\right)$ & & 0.94 & 0.93 & 0.89 & 0.0062 & 7.08 & 0.0010 & 226.78 & $<0.0001$ & 39.96 \\
\hline Total Cost $\left(€ / \mathrm{m}^{3}\right)$ & & 0.98 & 0.97 & 0.93 & 0.0185 & 8.21 & 0.0123 & 79.10 & $<0.0001$ & 28.43 \\
\hline
\end{tabular}
our experimental results [47]. Based on descriptive statistics, generated models can be used to reveal the process behavior.

\subsection{Effect of variables}

It was determined that initial $\mathrm{pH}$, current density and electrolysis time had remarkably effect on decol-

Table 4. ANOVA results

AP: Adequate Precision, CV: Coefficient of Variance, PRESS: Predicted Residual Error sum of squares, SD: Standard Deviation 

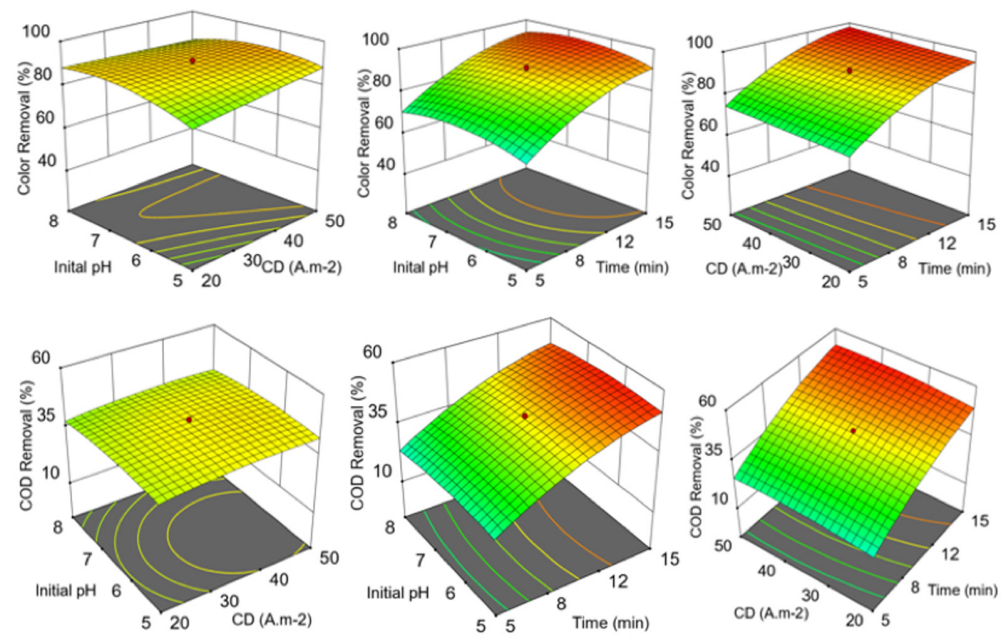

Fig. 1. Profile of COD removal and decolorization for Fe-Fe electrode pair.

orization and COD reduction for $\mathrm{Al}-\mathrm{Al}$ and $\mathrm{Fe}-\mathrm{Fe}$ electrode pairs. All of them were statistically significant $(p<0.005)$. 3D surface response plots (Fig. 1 for $\mathrm{Fe}-\mathrm{Fe}$ electrode pair and Fig. 2 for Al-Al electrode pair) were prepared to estimate the effect of independent variables on COD reduction and decolorization. In each plot, two variables were demonstrated while the other one was kept at center point $(a=0)$.

EC is one of the methods frequently used to achieve the desired success in the treatment of textile wastewater. The optimum $\mathrm{pH}$ value determination is very important. $\mathrm{pH}$ controls the generation of monomeric and polymeric species which have different absorbing properties based on the electrode type in the aqueous solution. It was determined that COD removal efficiency increased up to $43 \%$ by increasing $\mathrm{pH}$ value to 5.8 and decolorization increased up to $90 \%$ when the $\mathrm{pH}$ value was increased to 6.8 for FeFe electrode pair. The amount of flock generation related with current density and electrolysis time according to the Faraday law. Increased electrolysis period and current density resulted in increased COD reduction and decolorization.

When the operating cost was not considered, $52 \%$ COD reduction and $97 \%$ decolorization were obtained for $\mathrm{Fe}-\mathrm{Fe}$ electrode pair at the highest current density $\left(50 \mathrm{~A} / \mathrm{m}^{2}\right.$ ) and electrolysis time (15 min). Limited COD reduction can be explained by the fact that all COD in the DDW was dissolved. Disperse dyes can be treated with EC process at shorter elec- trolysis times and current densities due to their hydrophobic nature. Similarly, in a previous study with DDW without auxiliary chemicals, it was reported that decolorization was achieved within a short electrolysis time of $4.5 \mathrm{~min}$ [48]. Based on another study conducted with stainless steel electrodes, the electrolysis time of 10-15 minutes was sufficient for approximately 55\% COD removal and $100 \%$ decolorization, with an optimum $\mathrm{pH}$ range of 5.5 to 9.5 [49]. In addition, it is reported that less chemical is used for disperse dyestuffs than reactive dyestuffs in chemical coagulation processes [20].

As seen in Fig. 2, to obtain highest COD reduction and decolorization for Al-Al electrode pair, $\mathrm{pH}$ should be in the range of 5.0-7.0 to form $\mathrm{Al}(\mathrm{OH})_{3}$ in solid form. Therefore, the initial $\mathrm{pH}$ value was very important. When the initial $\mathrm{pH}$ was increased from 5.0 to 8.0, there was no change in COD removal efficiency $(\approx 45 \%)$, but a decrease in color removal. At the same time, similar to another studies, when aluminum electrode was used, COD and color removal efficiencies increased as electrolysis time and current density increased [50].

Design Expert software used for numerical optimization of the experimental conditions (independent variables) such as initial $\mathrm{pH}$, current density and electrolysis time to maximize the COD removal efficiency and decolorization and to minimize the total operating costs included energy, electrode and chemical consumption and sludge handling based on the 

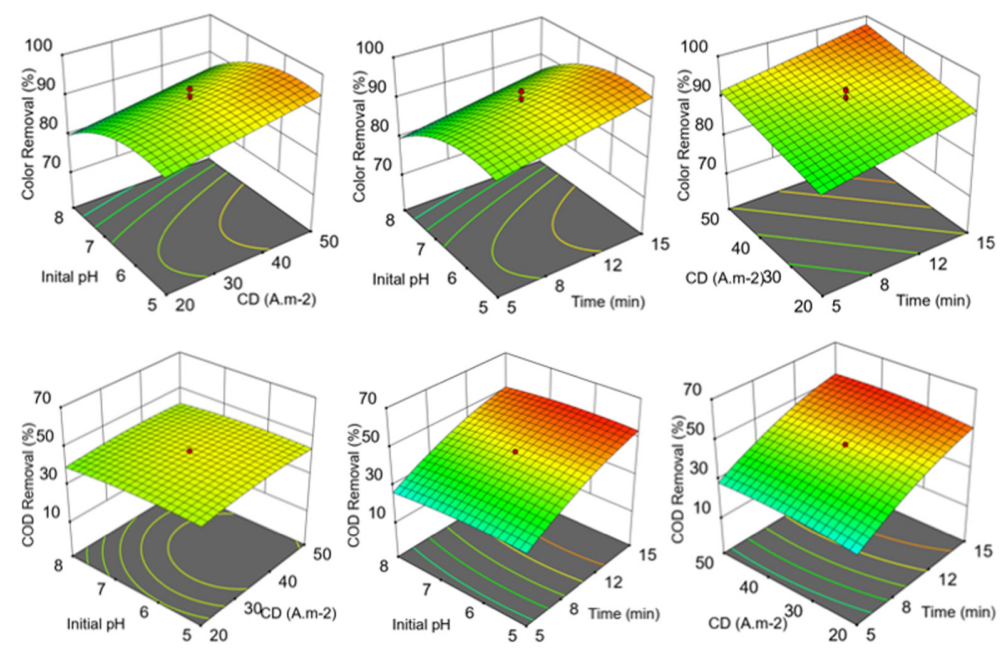

Fig. 2. Profile of COD removal and decolorization for Al-Al electrode pair.

desirability functions. The goals for each independent variable were selected in the range as criteria, while the goal is to maximize the response variable in terms of COD removal efficiency and decolorization and is to minimize the total operating cost. Same weight and the same importance were selected both dependent and independent variables. For the Al-Al electrode pair, a current density of $20 \mathrm{~A} / \mathrm{m}^{2}$, an electrolysis period of 15 minutes and an initial $\mathrm{pH}$ of 5.3 were determined as optimum operating conditions to achieve $92.8 \%$ decolorization and $51.3 \%$ COD removal efficiency with operating cost of $0.19 € / \mathrm{m}^{3}$ treated wastewater. However, if the $\mathrm{Fe}-\mathrm{Fe}$ electrode pair was used, a current density of $20 \mathrm{~A} / \mathrm{m}^{2}$, an electrolysis period of 15 minutes and an initial $\mathrm{pH}$ of 6.20 were determined as optimum operating conditions to achieve $90.5 \%$ decolorization and $49.2 \%$ COD removal efficiency with operating cost of $0.20 € / \mathrm{m}^{3}$ treated wastewater. Al-Al electrode pair are proved to be better than the Fe-Fe electrode pair in the present study.

At the optimum, cost items were determined as energy $\left(0.269 \mathrm{kWh} / \mathrm{m}^{3}\right.$ equal to $0.019 € / \mathrm{m}^{3}$ for $\mathrm{Al}-\mathrm{Al}$ electrode pair and $0.252 \mathrm{kWh} / \mathrm{m}^{3} 0.018 € / \mathrm{m}^{3}$ for FeFe electrode pair), electrode $\left(0.059 \mathrm{~kg} / \mathrm{m}^{3}\right.$ equal to $0.097 € / \mathrm{m}^{3}$ for Al-Al electrode pair and $0.089 \mathrm{~kg} / \mathrm{m}^{3}$ equal to $0.076 € / \mathrm{m}^{3}$ for $\mathrm{Fe}-\mathrm{Fe}$ electrode pair), chemical consumption $\left(0.058 € / \mathrm{m}^{3}\right.$ for Al-Al electrode pair and $0.081 € / \mathrm{m}^{3}$ for Fe-Fe electrode pair) and sludge handling $\left(0.18 \mathrm{~kg} / \mathrm{m}^{3}\right.$ equal to $0.016 € / \mathrm{m}^{3}$ for $\mathrm{Al}-\mathrm{Al}$ electrode pair and $0.28 \mathrm{~kg} / \mathrm{m}^{3}$ equal to $0.025 € / \mathrm{m}^{3}$ for Fe-Fe electrode pair).

Eventually, total operating cost components included energy, electrode and chemical consumption and sludge handling were determined as $10.0 \%$, $51.1 \%, 30.5 \%$ and $8.4 \%$ for Al-Al electrode pairs, and $9.0 \%, 38.0 \%, 40.5 \%$ and $12.5 \%$ for Fe-Fe electrode pairs, respectively. The results showed that there are significant differences between the contribution of cost items on total cost, even though the costs are relatively equal. Al-Al electrode pair gives better decolorization and COD reduction at lower $\mathrm{pH}$. Based on our results, it is simply seen that operating cost items change mostly based on $\mathrm{NaOH}$ utilization to regulate inital $\mathrm{pH}$ due to the low $\mathrm{pH}$ of DDW which was neglected in many previous studies.

\subsection{Verification of optimized conditions using syn- thetic and real DDW}

The appropriateness of the predictive model equation was tested using optimal conditions to determine the optimal response values for synthetic DDW. The predicted COD and decloarization values were in close agreement with the experimental values (error $<5 \%$ ) and were found to be not significantly different using paired t-test [51]. In experimental studies were conducted with real wastewater, 93.0\% of decolorization and $51.5 \%$ of COD reduction were obtained with sludge production of $185 \mathrm{mg} / \mathrm{L}$ for Al$\mathrm{Al}$ electrode pair, while $92.2 \%$ of decolorization and 
$46.9 \%$ of COD reduction were obtained with sludge production of $276 \mathrm{mg} / \mathrm{L}$ for an $\mathrm{Fe}-\mathrm{Fe}$ electrode pair. The current experimental results confirmed that the prediction models were of sufficient accuracy and precision in verification studies conducted with both synthetic and real wastewater.

\subsection{Kinetic study}

The treated samples were collected at 5-minute intervals to monitor changes in decolorization and COD reduction from the EC at the optimum operating condition for kinetic assessment. Kinetic evaluation of EC process using both Al-Al and Fe-Fe electrode pair indicated that COD removal and decolorization fitted fairly well the first-order kinetic rules (Eq. 1).

$$
C_{t}=C_{0} \cdot e^{k_{1} \cdot t}
$$

Where $\mathrm{k}_{1}$ is the first-order rate constant in $1 / \mathrm{min}$, $\mathrm{C}_{\mathrm{t}}$ is effluent COD $(\mathrm{mg} / \mathrm{L})$ or Color $(1 / \mathrm{cm})$, $\mathrm{t}$ is electrolysis time.

The removal rate can be obtained from the slope of straight line as a kinetic coefficient for COD reduction and decolorization. Decolorization rate constants were calculated as $0.21 \mathrm{1} / \mathrm{min}$ and $0.201 / \mathrm{min}$ for Al$\mathrm{Al}$ and Fe-Fe electrode pair, respectively. Similarly, researchers reported that decolorization rate constant for textile dye increased from $0.261 / \mathrm{min}$ to $0.34 \mathrm{1} /$ $\mathrm{min}$ by increased current density from $2.0 \mathrm{~mA} / \mathrm{cm}^{2}$ to $4.5 \mathrm{~mA} / \mathrm{cm}^{2}$ [19]. COD reduction has a lower kinetic constant compared to decolarization. The first order COD reduction rate constants were determined as $0.051 \mathrm{l} / \mathrm{min}$ and $0.047 \mathrm{1} / \mathrm{min}$ for Al-Al and Fe-Fe electrode pair, respectively. In another study con- ducted using real wastewater, COD reducation rate constants were $0.0501 / \mathrm{min}, 0.0261 / \mathrm{min}$ and 0.044 $1 / \mathrm{min}$ for $\mathrm{Fe}-\mathrm{Fe}, \mathrm{Al}-\mathrm{Al}$ and $\mathrm{Al}-\mathrm{Fe}$ electrodes pairs, respectively [52]. These results show that electrode material has a significant effect on COD reduction rate.

\subsection{Sludge Production}

In electrocoagulation processes, coagulant is produced electrochemically. In this process, metal dissolution occurs in the anode in accordance with faraday laws, while water reduction in the cathode. The formation of polymeric and monomeric aluminum/iron compounds based on electrode materials can be explained by complex electrochemical reactions and solution $\mathrm{pH}$ [53]. Therefore, it is important to determine the relationship between sludge formation and actual electrode consumption. The relationship between electrode consumption and sludge production are illustrated in Fig. 3.

The increase theoretical dissolution as a function of applied current and electrolysis time was confirmed by the measuring the amount of produced sluge. At the optimum condition, the amount of generated sludges were $0.18 \mathrm{~kg} / \mathrm{m}^{3}$ (equal to $1.61 \mathrm{~g} / \mathrm{g}$ of dye removed) and $0.28 \mathrm{~kg} / \mathrm{m}^{3}$ (equal to $2.60 \mathrm{~g} / \mathrm{g}$ of dye removed) for $\mathrm{Al}-\mathrm{Al}$ and $\mathrm{Fe}-\mathrm{Fe}$ electrode pairs, respectively. Similar results reported at previous studies [54]. Experimental studies have shown that there was the linear relationship between electrode loss a nd sludge production.

\section{Conclusions}

In this study, the process variables affecting COD

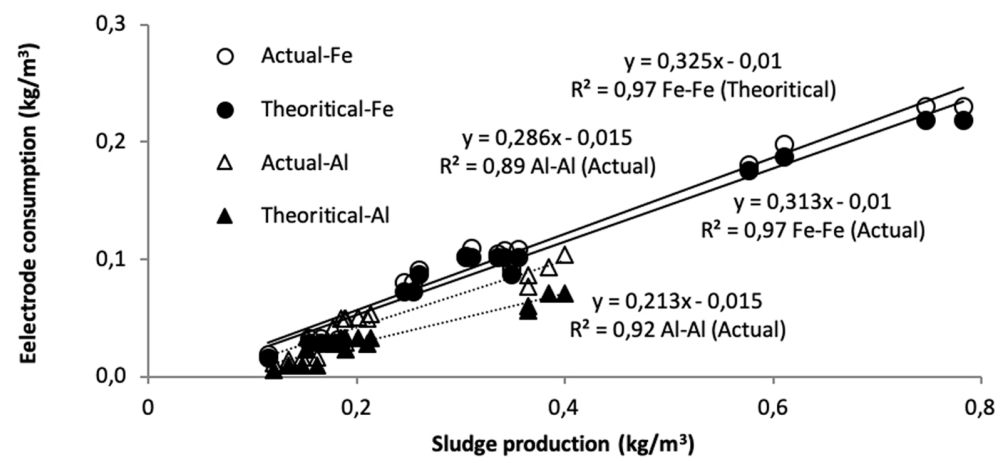

Fig. 3. The relationship between electrode consumption and sludge production. 
removal and decolorization from DDW simulated by a batch-operated laboratory scale EC were optimized using RSM. The Al-Al electrode pair was proved to be better than Fe-Fe electrode pair as a sacrificial electrode material in terms of COD removal and decolorization with low operating cost. The results showed that there is a significant difference between the cost items, even though the operating costs are relatively equal for treatment of DDW. Although it has been neglected in many studies, the chemical cost required for $\mathrm{pH}$ regulation had a significant share in the total cost. In addition, it was obviously deductible that the decolorization was occurred more quickly than COD removal for both electrodes based on kinetic rate constants. Experimental studies reveal that the there was a linear relationship between electrode loss a nd sludge generation.

\section{Acknowledgment}

The authors thank Cagatay YUCE (Pisa Textile Factory) for supplying the disperse dyes and auxiliary chemicals. The present study is financially supported by Selçuk University Scientific Research Project (Project No: 09101026). This paper was derived from a part of a Ph.D. thesis fulfilled by A. Aygun.

\section{References}

[1] K. Cirik, N. Dursun, E. Sahinkaya, O. Cinar, Bioresour. Technol., 2013, 133, 414-420.

[2] E. Tsantaki, T. Velegraki, A. Katsaounis, D. Mantzavinos, J. Hazard. Mater, 2012, 207-208, 91-96.

[3] S.T. Akar, A. Gorgulu, Z. Kaynak, B. Anilan, T. Akar, Chem. Eng. J., 2009, 148(1), 26-34.

[4] M. Meinke, M. Abdollahnia, F. Gähr, T. Platzek, W. Sterry, J. Lademann, Exp. Dermatol., 2009, 18(9), 789792.

[5] V. Faraco, C. Pezzella, P. Giardina, A. Piscitelli, S. Vanhulle, G. Sannia, J. Chem. Technol. Biotechnol., 2009, 84(3), 414-419.

[6] T. Robinson, G. McMullan, R. Marchant, P. Nigam, Bioresour. Technol., 2001, 77(3), 247-255.

[7] D. Yang, H. Li, Y. Qin, R. Zhong, M. Bai, X.Q. Qiu, J. Dispers. Sci. Technol., 2015, 36(4), 532-539.

[8] A. Ujhelyiova, E. Bolhova, J. Oravkinova, R. Tiňo, A. Marcinčin, Dye. Pigment., 2007, 72(2), 212-216.

[9] S. Altun, Color. Technol., 2005, 121(2), 69-71.

[10] J.J. Lee, W.J. Lee, J.P. Kim, Fibers Polym., 2003, 4(2), 66-70.

[11] J. Akrman, J. Přikryl, J. Appl. Polym. Sci., 1997, 66(3),
543-550.

[12] S.M. Burkinshaw, G. Salihu, Dye. Pigment., 2013, 99(3), 548-560.

[13] I.A. Alaton, G. Insel, G. Eremektar, F.G., Babuna, D. Orhon, Chemosphere, 2006, 62(9), 1549-1557.

[14] K. Sarayu, S. Sandhya, Appl. Biochem. Biotechnol., 2012, 167(3), 645-661.

[15] I. Arslan, J. Hazard. Mater., 2001, 85(3), 229-241.

[16] M. Karatas, Y.A. Argun, M. E. Argun, J. Ind. Eng. Chem., 2012, 18(3), 1058-1062.

[17] I. Anastopoulos, A. Hosseini-Bandegharaei, J. Fu, A. C. Mitropoulos, G. Z. Kyzas, J. Dispers. Sci. Technol., 2018, 39(6), 836-847.

[18] S. Sahinkaya, J. Ind. Eng. Chem., 2013, 19(2), 601-605.

[19] T. H. Kim, C. Park, E. B. Shin, S. Kim, Desalination., 2002, 150(2), 165-175.

[20] B. Merzouk, B. Gourich, K. Madani, C. Vial, A. Sekki, Desalination., 2011, 272(1-3), 246-253.

[21] C. Phalakornkule, S. Polgumhang, W. Tongdaung, B. Karakat, T. Nuyut, J. Environ. Manage., 2010, 91(4), 918-926.

[22] B.K. Nandi, S. Patel, J. Dispers. Sci. Technol., 2013, 34(12), 1713-1724.

[23] F. Ilhan, K. Ulucan-Altuntas, C. Dogan, \& U. Kurt, Global NEST J., 2019, 21(2), 187-194.

[24] S. Bener, O. Bulca, B. Palas, G. Tekin, S. Atalay, G. Ersoz, Process Saf. Environ. Prot., 2019, 129, 47-54.

[25] M. Bayramoglu, M. Kobya, O.T. Can, M. Sozbir, Sep. Purif. Technol., 2004, 37(2), 117-125.

[26] A. Dimoglo, P. Sevim-Elibol, O. Dinc, K. Gokmen, H. Erdogan, J. Water Process. Eng., 2019, 31, 100877

[27] D. Gunawan, V. B. Kuswadi, L. Sapei, L. Riadi, Environ. Eng. Res., 2018, 23(1), 114-119.

[28] I. Arslan-Alaton, M. Kobya, A. Akyol, M. Bayramoğlu, Color. Technol., 2009, 125(4), 234-241.

[29] N. Daneshvar, A. Oladegaragoze, N. Djafarzadeh, $J$. Hazard. Mater, 2006, 129(1-3), 116-122.

[30] A. S. Naje, S. Chelliapan, Z. Zakaria, S.A. Abbas, J. Environ. Manage., 2016, 176, 34-44.

[31] R. Keyikoglu, O. T. Can, A. Aygun, A. Tek, Colloids Interface Sci. Commun., 2019, 33, 100210

[32] M. M. Hossain, M. I. Mahmud, M. S. Parvez, H. M. Cho, Environ. Eng. Res., 2013, 18(3), 157-161.

[33] A. Alinsafi, M. Khemis, M. N. Pons, J. P. Leclerc, A. Yaacoubi, A. Benhammou, A. Nejmeddine, Chem. Eng. Process. Process Intensif., 2005, 44(4), 461-470.

[34] J. N. Hakizimana, B. Gourich, M. Chafi, Y. Stiriba, C. Vial, P. Drogui, J. Naja, Desalination., 2017, 404, 1-21.

[35] A. S. Assémian, K. E. Kouassi, P. Drogui, K. Adouby, D. Boa, Water. Air. Soil Pollut., 2018, 229(6), 184

[36] O. Gul, I. Atalar, F.T. Saricaoglu, F. Yazici, J. Food Process. Preserv., 2018, 42(5), e13615.

[37] M.M. Nourouzi, T.G. Chuah, T.S.Y. Choong, Water Sci. Technol., 2011, 63(5), 984-995.

[38] E. K. Tetteh, D. B. Naidoo, S. Rathilal, Eng. Res., 2019, 24, Issue 4. 
[39] S. Sharma, A. Aygun, H. Simsek, Chemosphere, 2020, 249,126511

[40] S. Sharma, H. Simsek, Chemosphere, 2019, 221, 630639.

[41] W.T. Mook, M. K. Aroua, M. Szlachta, C. S. Lee, Water Sci. Technol., 2017, 75(4), 952-962.

[42] A. Aygun, B. Nas, M.F. Sevimli, Korean J. Chem. Eng. 2019, 36(9), 1441-1449.

[43] Y. Yavuz, B. Ogutveren, J. Environ. Manage., 2018, 207, 151-158.

[44] E. Demirbas, M. Kobya, Process Saf. Environ., 2017, $105,79-90$

[45] T. Olmez, J. Hazard. Mater. 2009, 162(2-3), 1371-1378.

[46] A. Aygun, S. Dogan, M. E. Argun, H. Ates, Environ. Eng. Res., 2019, 24(1), 24-30.

[47] E. Gengec, M. Kobya, E. Demirbas, A. Akyol, K. Oktor, Water Sci. Technol., 2012, 65(12), 2183-2190.
[48] W. Lemlikchi, S. Khaldi, M. O. Mecherri, H. Lounici, N. Drouiche, Sep. Sci. Technol., 2012, 47(11), 16821688 .

[49] I. Arslan-Alaton, G. Turkoglu, G. Environ. Eng. Sci., 2008, 25(3), 295-307.

[50] I. Kabdasli, B. Vardar, I. Arslan-Alaton, O. Tunay, Chem. Eng. J., 2009, 148(1), 89-96.

[51] M. B. Hossain, N. P. Brunton, A. Patras, B. Tiwari, C.P. O'Donnell, A.B. Martin-Diana, C. Barry-Ryan, Ultrason. Sonochem., 2012, 19(3), 582-590.

[52] I. Linares-Hernández, C. Barrera-Díaz, G. Roa-Morales, B. Bilyeu, F. Ureña-Núñez, Chem. Eng. J., 2009, 148(1), 97-105.

[53] R. Khosravi, S. Hazrati, M. Fazlzadeh, Desalin. Water Treat., 2016, 57(31), 14656-14664.

[54] B. K. Nandi, S. Patel, Arab. J. Chem., 2017, 10, S2961S2968. 